Article

\title{
Developing a Competitive and Sustainable Destination of the Future: Clusters and Predictors of Successful National-Level Destination Governance across Destination Life-Cycle
}

\author{
Ivan Paunović ${ }^{1, *(\mathbb{D})}$, Marc Dressler ${ }^{2}$, Tatjana Mamula Nikolić ${ }^{3}$ and Sanja Popović Pantić 4 \\ 1 Dienstleistungszentrum Ländlicher Raum Rheinpfalz, 67435 Neustadt and der Weinstraße, Germany \\ 2 Hochschule für Wirtschaft und Gesselschaft Ludwigshafen, 67435 Neustadt and der Weinstraße, Germany; \\ marc.dressler@hwg-lu.de \\ 3 Metropolitan University, 11000 Belgrade, Serbia; tatjana.mamula@metropolitan.ac.rs \\ 4 Institute "Mihajlo Pupin”, University of Belgrade, 11060 Belgrade, Serbia; sanjap.pantic@pupin.rs \\ * Correspondence: paun.bg@gmail.com
}

Received: 15 April 2020; Accepted: 13 May 2020; Published: 15 May 2020

\begin{abstract}
This study advances the research and methodological approach to measuring and understanding national-level destination competitiveness, sustainability and governance, by creating a model that could be of use for both developing and developed destinations. The study gives a detailed overview of the research field of measuring destination competitiveness and sustainability. It also identifies major predictors of destination competitiveness and sustainability and thereby presents destination researchers and practitioners with a useful list of priority areas, both from a global perspective and from the perspective of other similar destinations. Finally, the study identifies two major types of destination governance with implications for research, policy and practice across the destination life-cycle. The research deals with the analysis of the secondary data from the World Economic Forum Travel and Tourism Index (WEF T\&T). Major types of destination governance and predictors of belonging to either one of the types, as well as inside cluster predictors have been extracted through a two-step cluster analysis. The results support the notion that a meaningful model of national-level destination governance needs to take into account different development levels of different destinations. The main limitation of the study is its typology creation approach, as it inevitably leads to simplifications.
\end{abstract}

Keywords: innovation; indicators; governance; sustainability; competitiveness; destination; life-cycle

\section{Introduction}

A destination's success depends on its competitiveness in the global market, but also on the need to sustain its competitive position and be resilient in the face of unforeseen events as a prerequisite of long-range success [1,2]. This is a difficult task, because destinations are being produced and reproduced through a complex combination of social, cultural, political and economic relationships, making tourism research a transdisciplinary field of research, which beyond business research includes spatial issues (local, regional, national), thematic issues (mobility, culture, sustainability) and different approaches (advocacy, cautionary, adaptive and knowledge-based platforms) [3-5].

There is a gap in the literature on the most significant factors of destination performance that could be of use for both policy and organizations [6]. This exploratory study therefore seeks to fill this gap by creating a taxonomy model that could provide more flexibility in understanding the types of challenges faced by different destinations, and at the same time acknowledging that a global model of 
destination excellence needs to take into account a multitude of approaches to destination planning and development. For creating a taxonomy model, research deploys a two-step cluster analysis of the data from the two Travel and Tourism Competitiveness reports (Crotti and Misrahi [7] and Crotti and Misrahi [8]), thereby answering the call from Dwyer and Kim [9] for further research of data on competitiveness from the World Economic Forum.

Understanding major predictors of destination competitiveness is of essential importance for destination planning and governance arrangements. The importance of specific predictors (both in global terms and in terms of a narrower competitive set) is important for setting the agenda for discussions on the future destination planning and governance, and aligning the destination-level goals with the changes in the competitive set and in the global competitive landscape.

The article identifies major national-level destination competitiveness and governance types, predictors of belonging to either one of the types identified, as well as predictor importance inside each of the two competitiveness and governance types. Before presenting the results, a literature review summarizes previous articles on indicators of destination competitiveness and destination governance, while the discussion positions the results within the two research fields.

\section{Literature Review}

\subsection{Competition, Competitiveness}

Destination competitiveness is measured through specific competitiveness factors, especially focusing on specific factor sets that are of relevance in a specific destination competitiveness group and specific destination life-cycle stage [10-13]. Competition in general business terms is about success and about outperforming the others in a particular market by aligning one's firm's activities according to priorities and establishing a profitable and sustainable industry position [14,15]. However, regarding the competition between tourism destinations, it is a more complex phenomenon than inter-organizational competition for a number of reasons: (a) national tourist destinations belong to a specific (and non-changeable) competitive set because of geographic position, previous involvement with the global tourism industry and natural and cultural resources [16,17]; (b) there is a pronounced difference between inherited/endowed resources and created resources [9]; (c) the degree of (potential) tourist product complementarity determines the optimal level of competition or cooperation between regional destinations in the global market [18]; (d) major drivers of competitiveness are often non-economic, e.g., enhancing the well-being of destination residents or preserving natural resources $[19,20]$. The problem with applying the concept of competitiveness on national-level tourism destinations is that competitiveness is often viewed from the short-term perspective, particularly in times of crisis, to include strong promotional activities on international tourism markets, decreasing costs and identifying synergies between tourism actors [6]. An important distinction should be made at this point regarding comparative advantage (e.g., an abundance of natural resources, low labor costs) and competitive advantage (the ability to add value to the resources in order to sell them on the market) [21-24]. Competitive advantage represents the value that can be produced for the buyers that can exceed the cost of creating this value: value in this sense is what buyers are willing to pay [15]. Benchmarking is a tool often used for analyzing a destination's competitive position [25]. It can be conducted as internal, competitive, functional or generic, and it is an especially good tool for monitoring qualitative aspects of tourism development to systematically analyze performance, processes and strategies [26-30].

\subsection{Determinants of Destination Competitiveness and Sustainability along the Destination Life-Cycle}

Before making a more nuanced analysis of destination development, it is first important to understand what represents a successful tourism destination and what does not. This paragraph gives a short literature overview for indicators of destination and/or tourism performance. For a full list of major studies in this field please refer to Table 1 at the end of the literature review or consult the a 
review provided by Medina-Munoz et al. [31]. Assaf and Josiassen [6] identified the ten most negative and positive indicators of tourism performance. Taking into consideration these identified indicators, the goal for destination development would be to strive towards excellence to become, as Gilbert [32] defines it, "status areas" rather than "commodity areas", and attract high spenders and loyal tourists. The most significant obstacle in achieving this is that too extensive lists of destination competitiveness predictors lead to a need for determining the importance of each one of the predictors, as not each and every one can be of the same importance [10]. This is a major research gap identified in the literature that this article seeks to close, by providing a more usable set of most-relevant indicators for both developing and developed destinations.

The destination life-cycle model provides an argument that in developing destinations, demand should firstly exceed the supply, followed by a readjustment period in more mature phases, where high economic, social and environmental tourism impacts need to be managed [13]. However, later studies posit that tourism policy and decision making in developing countries needs to move away from putting a sole emphasis on quantitative measures of economic growth and enable qualitative measuring and destination development through better local stakeholder consultation early on in the destination development process [33-37]. In mature destinations, growth strategies are often connected to new product development that includes the expansion of: (1) networking between the actors, (2) customer value, and (3) competitiveness [38]. This is usually achieved by connecting destination resource space with activity space and experience space. Goffi and Cucculelli [39] single out in their research destinations of excellence (developed destinations) either based on their environmental standards (primarily related to water quality) or based on their built heritage and public services and activities, located within small, usually rural communities. In most rural destinations the emphasis is on creating tourism products related to natural resources, while in urban destinations, such as Dubai, the focus in on building global air accessibility as well as luxurious accommodation facilities [40,41].

Special attention should be given to emerging themes, such as Internet-related technology. In this sense, knowledge and innovation need to be the core value of tourism destination planning and development in order for the destination to survive in the global competitive environment [42,43]. The Internet and social media are one of the major megatrends having an impact on the society as a whole, and especially tourism, as a wide range of data is now available to tourists on the go: landscape descriptions, pricing, accommodation rating and local news [44]. Standing in relation to this aspect is the growing social importance of a digitally affluent generation, namely the millennials (generation $\mathrm{Y}$ ), as they represent the future of both consumers and the job market, by including their vacation habits, sustainability attitudes, social media usage patterns, increasing participation in luxury markets and workplace preferences [45-47]. As consumers, millennials are often non-traditionalist in their choices even for luxury products $[48,49]$.

Sustainability should play an important role in fostering long-term tourism destination competitiveness in developing destination [50-52], but it is even more important for the competitiveness of the developed destinations. One of the most important obstacles for implementation of sustainable tourism in developing destinations consists of managerial values and social representations of sustainability [53]. Regarding specific indicators, one of the major factors identified in the literature is air quality [54-56], especially in city destinations like Beijing, Dubai or Belgrade [41,57-59]. Other frequent environmental issues in destinations like Egypt, China, India, Montenegro, Croatia and Serbia include water pollution and inappropriate garbage disposal [58,60-62],

\subsection{Destination Planning, Development and Governance}

Destination governance encompasses both corporate and public governance and can mean both the architecture of relationships between public and private actors and the process of steering the society [63]. Angella, et al. [64] have extracted four types of destination governance: normative, leading firm, entrepreneurial and fragmented (scattered governance function, weak coordination mechanism). Major obstacles of national tourism destination governance include a complex and 
diffused action field and a limited reach when it comes to private actors at the destination [65]. Other destination governance problems include: lack of, or inefficient, soft and interdisciplinary planning instruments; an insignificant role of destination residents in decision-making; a dominant role of foreign tour operators; and a power-distant government department and/or destination management organization $[53,66,67]$. In addition, DMOs (Destination Management Organizations) should be equipped with financial means and political and legislative power in order to be able to manage the interests, benefits and responsibilities of tourists, host population, tourism enterprises, tour operators and the public sector [13].

Successful destination governance needs to include common goals, a balanced power between the actors and co-evolutionary adaptations [68-71]. The phenomena related to poor governance mostly include hierarchical structures, lack of inclusion trust and perceived justice from actors [70,72], while the new and emerging theme in destination governance are public-private partnerships [73,74]. Nadalipour, et al. [75] call for future research on identifying a globally applicable model for investigation of tourist destinations in different contexts and their sustainability and competitiveness, by deploying multidisciplinary indicators of sustainable competitiveness. This research closes this research gap by acknowledging that a globally applicable destination governance model needs to be flexible enough to be used in different types of settings-both in terms of mutual relationships between major tourism actors as well as regarding processes steering tourism development. The reason for this is that different forms of multi-actor, networked collaboration arrangements directly impact the innovation of place-based competitiveness and sustainability policy [76-80]. This approach is becoming even more relevant in light of disruption caused by new technologies in the service industries: from tourism to hospitality and to mobility, new business models are disrupting business-as-usual and challenging the regulatory frameworks and the existing balance of power between the destination actors [81-84].

Sustainability is one of the most important concepts for the future of tourism governance [42,85]. However, as has been demonstrated in the literature, tourism has improved the socioeconomic conditions only in the most developed countries, while developing countries have problems with the implementation of sustainable tourism concepts because of pressurized political contexts: large-scale capital-intensive real estate projects are encouraged without having (or disregarding) an integrated plan to account for environmental and local community impacts [86-90]. 
Table 1. Overview of major tools, concepts and statistical methods deployed to measure destination competitiveness.

\begin{tabular}{|c|c|c|c|c|}
\hline $\begin{array}{l}\text { Concept of Observable } \\
\text { Variable }\end{array}$ & $\begin{array}{l}\text { Concept of Non-Observable } \\
\text { Mediating Variable }\end{array}$ & Researched Concept & Statistical/Other Method & Author \\
\hline 30 determinants & 8 drivers & Tourism performance & Descriptive statistics, regression & [6] \\
\hline 93 indicators & $\begin{array}{l}7 \text { factors/determinants (with } \\
\text { subcategories) }\end{array}$ & $\begin{array}{c}\text { Tourism competitiveness as a means towards national } \\
\text { economic prosperity }\end{array}$ & Theory building based on literature review & [9] \\
\hline 37 subfactors/attributes & 5 factors/determinants & Destination competitiveness and sustainability & AHP (Analytic hierarchy process) & [10] \\
\hline 57 indicators & 6 factors & $\begin{array}{l}\text { Destination competitiveness as a means towards welfare and } \\
\text { socioeconomic prosperity of residents }\end{array}$ & $\begin{array}{c}\text { Descriptive statistics, FE (fixed effect) } \\
\text { estimator }\end{array}$ & [19] \\
\hline 62 attributes & $\begin{array}{l}8 \text { macro attributes, dependent } \\
\text { variables, tourism outcomes }\end{array}$ & Destination competitiveness and sustainability & PCA (Principal Component Analysis) & [50] \\
\hline $\begin{array}{l}36 \text { attributes } \\
64 \text { indicators }\end{array}$ & $\begin{array}{l}5 \text { factors } \\
13 \text { determinants/components }\end{array}$ & $\begin{array}{c}\text { Competitiveness of small- and medium-sized destinations } \\
\text { Competitiveness of small destinations }\end{array}$ & $\begin{array}{c}\text { PCA, partial least square regression } \\
\text { PCA }\end{array}$ & $\begin{array}{l}{[91]} \\
{[39]}\end{array}$ \\
\hline 51 items/activities & 6 categories & $\begin{array}{c}\text { Importance-performance analysis of destination } \\
\text { competitiveness }\end{array}$ & IPA (Importance-Performance Analysis) & {$[52]$} \\
\hline 83 indicators & 12 attributes, factors & PCA of destination competitiveness & PCA, importance-performance analysis & [92] \\
\hline 34 attributes & 5 determinants/factors & $\begin{array}{l}\text { Difference between destination competitiveness priorities } \\
\text { between public and private stakeholders }\end{array}$ & T-test & [93] \\
\hline 64 indicators/items & 13 components & Destination competitiveness & PCA & [94] \\
\hline 45 variables/action items & 5 factors & Destination competitiveness in the public and private sectors & $\begin{array}{l}\text { EFA (Exploratory Factor Analysis), CFA } \\
\text { (Confirmatory Factor Analysis) }\end{array}$ & [51] \\
\hline 205 variables/indicators & 29 elements & $\begin{array}{l}\text { Destination competitiveness of mountain destinations } \\
\text { through several objective, and an extensive set of subjective } \\
\text { (supply and demand side) measures }\end{array}$ & $\begin{array}{c}\text { Descriptive statistics, ANOVA (Analysis } \\
\text { of Variance) }\end{array}$ & [95] \\
\hline 33 global indices & 4 quadrants & $\begin{array}{c}\text { Country destination competitiveness in the regional (mostly } \\
\text { neighboring countries) tourism market }\end{array}$ & Importance-performance analysis & [16] \\
\hline 34 indicators & 2 groups & $\begin{array}{c}\text { Country destination competitiveness, as viewed by four types } \\
\text { of tourism stakeholders }\end{array}$ & Descriptive statistics & [17] \\
\hline 23 indicators & 2 groups & $\begin{array}{c}\text { The impact of tourist destination elements on tourist' } \\
\text { satisfaction }\end{array}$ & $\begin{array}{l}\text { Descriptive statistics, ANOVA, eta } \\
\text { square values }\end{array}$ & {$[60]$} \\
\hline 115 indicators & 5 groups—same as Crouch [10] & Suppliers' perception of destination competitiveness & $\begin{array}{l}\text { MANOVA (Multivariate Analysis } \\
\text { of Variance) }\end{array}$ & [96] \\
\hline 90 indicators & 14 drivers/pillars & $\begin{array}{l}\text { Global travel and tourism competitiveness (World Economic } \\
\text { Forum (WEF)), descriptive statistics, mixed method } \\
\text { (secondary data and expert questionnaire). }\end{array}$ & Descriptive statistics & {$[7,8]$} \\
\hline
\end{tabular}




\section{Methodology}

Although significant criticism of the World Economic Forum Travel and Tourism (WEF T\&T) data and their mixed collection method has been presented in the literature, it is considered to be the most complete and relevant global data collection effort regarding destination competitiveness and sustainability, and as such suitable for further discussion of national-level tourism policy [17,39,97]. Therefore, data from the 2015 and 2017 WEF T\&T reports [7,8] were used for this analysis. Data from previous reports $(2008,2009,2011$ and 2013) were excluded due to incompatible indicator selection due to considerably different methodology. The latest report (2019) was not yet available at the time of analysis. Firstly, the data from 2015 and 2017 were cleaned to include a consistent set of countries (131) and variables and indicators (86). A total of 10 countries and variables were deleted because they were not present in both reports, as well as two indicators that had missing values. For an additional four out of 86 indicators used, the data were present only in one of the two reports, and thus no average was calculated for these four indicators. For the remaining 82 indicators, the average of the indicator values from both reports (2015 and 2017) was calculated. For this data set, a two-step cluster analysis was calculated using IBM SPSS 23 software.

Regarding cluster quality in terms of their cohesion and separation, the average silhouette value was 0.5 , pointing to a good fit both by SPSS green color indication and as confirmed in the literature by Sarstedt and Mooi [98]. This was achieved by choosing a solution with 23 inputs and two clusters. There were four other solutions that reached the 0.5 silhouette value, all including the two-cluster solution, but with a higher number of inputs $(25,28,31$ and 34$)$. The solution with two clusters and 23 inputs was therefore deemed the most compact and useful model in this group. By deploying this procedure, answers to the following research questions were sought:

1. What are the major destination governance types globally?

2. What are major predictors of belonging to the identified destination governance types?

3. How do the two types differ in terms of the importance of specific indicators for destination governance or policy?

\section{Results}

By deploying a two-step analysis, two major types of destinations were extracted-developed ones (scoring higher on all relevant 23 indicators on average) and less developed ones (scoring lower on all relevant 23 indicators), as presented in Table 2. Firstly, the overall indicator relevance for the clustering solution was shown (in descending order), where indicators are called predictors. In order to further delve into the specificities of both clusters, in Table 3, the 23 indicators were presented according to their inside-cluster importance, in descending order.

The following predictors were used for the two-cluster solution: Wastewater treatment (1.00); Fixed broadband Internet subscriptions (0.81); Ground transport efficiency (0.80); Quality of roads (0.78); Quality of railroad infrastructure (0.75); Reliability of police services (0.72); Ease of finding skilled employees (0.69); Degree of customer orientation (0.68); Internet users (0.67); Quality of air transport infrastructure (0.66); Enforcement of environmental regulations (0.66); Paved road density (0.62); Mobile-broadband subscriptions (0.60); Quality of electricity supply (0.59); Quality of port infrastructure (0.57); Purchasing power parity (0.53); Number of international associations meetings (0.53); Number of operating airlines (0.46); Aircraft departures (0.45); Cultural and entertainment tourism digital demand (0.42); Pay and productivity (0.41); Stringency of environmental regulations (0.39); and Available seat kilometers, international (0.35). 
Table 2. Extracted clusters and major predictors in the two-step cluster analysis.

\begin{tabular}{clccc}
\hline Rank & Predictor Name & Importance & Cluster 1 Value & Cluster 2 Value \\
\hline 1 & Wastewater treatment & 1.00 & 15.64 & 75.76 \\
2 & Fixed broadband Internet subscriptions & 0.81 & 7.96 & 28.96 \\
3 & Ground transport efficiency & 0.80 & 3.23 & 5.05 \\
4 & Quality of roads & 0.78 & 3.65 & 5.44 \\
5 & Quality of railroad infrastructure & 0.75 & 3.58 & 5.22 \\
6 & Reliability of police services & 0.72 & 3.91 & 5.81 \\
7 & Ease of finding skilled employees & 0.69 & 3.84 & 4.85 \\
8 & Degree of customer orientation & 0.68 & 4.37 & 5.40 \\
9 & Internet users & 0.67 & 39.77 & 83.41 \\
10 & Quality of air transport infrastructure & 0.66 & 4.04 & 5.70 \\
11 & Enforcement of environmental regulations & 0.66 & 3.61 & 5.13 \\
12 & Paved road density & 0.62 & 3.74 & 5.54 \\
13 & Mobile-broadband subscriptions & 0.60 & 35.58 & 85.27 \\
14 & Quality of electricity supply & 0.59 & 4.10 & 6.33 \\
15 & Quality of port infrastructure & 0.57 & 3.59 & 5.41 \\
16 & Purchasing power parity & 0.53 & 0.47 & 1.00 \\
17 & Number of international associations meetings & 0.53 & 38.25 & 250.87 \\
18 & Number of operating airlines & 0.46 & 33.65 & 90.61 \\
19 & Aircraft departures & 0.45 & 3.98 & 29.42 \\
20 & Cultural and entertainment tourism digital demand & 0.42 & 9.89 & 35.76 \\
21 & Pay and productivity & 0.41 & 3.79 & 4.60 \\
22 & Stringency of environmental regulations & 0.39 & 3.83 & 5.72 \\
23 & Available seat kilometers, international & 0.35 & 269.98 & 2422.30 \\
\hline
\end{tabular}

Table 3. Cluster size and major inside-cluster predictors extracted in the two-step cluster analysis.

\begin{tabular}{|c|c|c|c|}
\hline \multicolumn{2}{|c|}{ Cluster 1 Size: $74.8 \%$ (98) } & \multicolumn{2}{|c|}{ Cluster 2 Size: $25.2 \%(33)$} \\
\hline $\begin{array}{l}\text { Within-Cluster } \\
\text { Importance Rank }\end{array}$ & Developing Destinations & $\begin{array}{l}\text { Within-Cluster } \\
\text { Importance Rank }\end{array}$ & Developed Destinations \\
\hline 1 & Available seat kilometers, international & 1 & Quality of electricity supply \\
\hline 2 & Aircraft departures & 2 & Internet users \\
\hline 3 & Purchasing power parity & 3 & Quality of roads \\
\hline 4 & $\begin{array}{l}\text { Number of international } \\
\text { associations meetings }\end{array}$ & 4 & Quality of air transport infrastructure \\
\hline 5 & Wastewater treatment & 5 & Paved road density \\
\hline 6 & Stringency of environmental regulations & 6 & Degree of customer orientation \\
\hline 7 & Fixed broadband Internet subscriptions & 7 & Quality of port infrastructure \\
\hline 8 & Ground transport efficiency & 8 & Ground transport efficiency \\
\hline 9 & Quality of railroad infrastructure & 9 & Ease of finding skilled employees \\
\hline 10 & $\begin{array}{l}\text { Cultural and entertainment tourism } \\
\text { digital demand }\end{array}$ & 10 & Reliability of police services \\
\hline 11 & Quality of roads & 11 & Wastewater treatment \\
\hline 12 & Number of operating airlines & 12 & Fixed broadband Internet subscriptions \\
\hline 13 & $\begin{array}{l}\text { Enforcement of } \\
\text { environmental regulations }\end{array}$ & 13 & Quality of railroad infrastructure \\
\hline 14 & Reliability of police services & 14 & $\begin{array}{l}\text { Enforcement of } \\
\text { environmental regulations }\end{array}$ \\
\hline 15 & Ease of finding skilled employees & 15 & Mobile-broadband subscriptions \\
\hline 16 & Mobile-broadband subscriptions & 16 & Pay and productivity \\
\hline 17 & Degree of customer orientation & 17 & Number of operating airlines \\
\hline 18 & Quality of air transport infrastructure & 18 & $\begin{array}{l}\text { Number of international } \\
\text { associations meetings }\end{array}$ \\
\hline 19 & Internet users & 19 & Purchasing power parity \\
\hline 20 & Paved road density & 20 & $\begin{array}{l}\text { Cultural and entertainment tourism } \\
\text { digital demand }\end{array}$ \\
\hline 21 & Quality of port infrastructure & 21 & Aircraft departures \\
\hline 22 & Quality of electricity supply & 22 & Stringency of environmental regulations \\
\hline 23 & Pay and productivity & 23 & Available seat kilometers, international \\
\hline
\end{tabular}

The two created clusters are presented in Table 3 (developed vs. developing), with the accompanying in-cluster importance of specific predictors. These results lay a foundation for differentiated destination governance theories for developing and developed destinations. 


\section{Discussion, Limitations and Future Research Directions}

Tourist destinations are often being compared regarding the number of overnight stays or tourist arrivals, the share of overnight stays or tourist arrivals in a specific market, or corresponding growth rates-an approach based on a classical TALC (Tourism Area Life Cycle) model of destination development $[12,99]$. However, dealing only with the number of tourist or overnights has its disadvantages, as it does not take into account prices or quality attributes $[95,100]$. More importantly, recent research has demonstrated the unreliability of official statistics due to manipulation of taxable overnight stays by accommodation providers [101]. This article fills this research gap by contributing to the existing knowledge on destinations competitiveness and sustainability, by providing benchmarking and indicator weighing for both developing and developed destinations. Two major types of destinations (developing and developed) were extracted, as well as one overall and two type-dependent predictor lists that enable better understanding of the global destination competitiveness.

The research results confirm the findings from the literature [19], that different destination competitiveness factors (predictors) have different impacts on the competitiveness of developing and developed destinations, going even further to rank the factors according to their relevance for both types of destinations. Identified predictors of global destination excellence, as well as inside-cluster relevance for both groups, should be further investigated and used for creating weighting schemes for indicator systems in different destinations. In other words, different indicators should be weighed in accordance with their importance (from 1.00 to 0.35 ), thereby closing to a big extent the research gap on weighing schemes, as identified by Zehrer, Smeral and Hallmann [95].

Having in mind the high relevance of the Internet-related indicators (Numbers 2, 9 and 13), more attention should be given to the Internet, social media, and how the digitally-oriented millennial generation is changing destinations globally-as consumers, as a workforce and as citizens in both developing and developed destinations.

The high importance of sustainability for tourism destination competitiveness on the global level, and especially for developed destinations, has been confirmed in the research. The results should serve as a starting point for tackling attitude-behavior gaps of destination managers and other stakeholders regarding sustainability. The environmental aspects captured by the model are: (1) Wastewater treatment, (11) Enforcement of environmental regulations, and (22) Stringency of environmental regulations. There is also a big difference in the municipal waste management and generally circular economy capabilities between developed and developing countries, which can all negatively affect the tourism industry in developing countries.

The research results emphasize the importance of a stable electricity supply and Internet use in developed destinations, coupled with physical infrastructure development, degree of customer orientation and workforce training and development, as well as reliable police services and wastewater treatment.

The research findings tackle the practical, managerial side, by extending the approach already deployed in the literature [93] and providing an alternative framework to be used on the national, regional or micro scale for accessing and weighing the competitiveness and sustainability of a destination in the global context. The findings also enhance the value of the Travel and Tourism Competitiveness Index, by making it more approachable for destination managers. The results also provide empirical evidence that quantitative growth in developing destinations (in this case of air transport traffic, purchasing power parity and international association meetings) needs to go hand in hand with wastewater treatment improvement and stringent environmental regulation, coupled with further digital and physical infrastructure development, as well as workforce training and development. There are also further considerations to be dealt with in politically unstable destinations (such as the island of Cyprus), where regional visitation is highly dependent on the perceptions of culture and ethnicity [102]. Similarly, post-war destinations face highly specific tourism development problems, such as lack of basic political prerequisites for the functioning of society, while the need for active re-branding and infrastructure re-development seems to be a top priority [103-108]. 
Considering the St. Gallen Model of Destination Management, being focused on developed destinations, it constantly redefines and updates the definition of a destination, and also discusses the DMO's role in a destination-level network, as well as destination leadership, strategy, resilience and governance arrangements $[109,110]$. However, the two-step clustering solution presented in the results section confirms the findings of previous studies, that there are significant differences in the process and outcomes of tourism development in the developed and developing countries $[90,111]$. Therefore, both types of destinations are presented in Figure 1, so as to better visualize the tourism destination governance arrangements and their mutual differences. The model builds on the premise that destinations first need to be in the type 1 destination governance mode in order to advance to the type 2 destination governance mode at a later point in time.

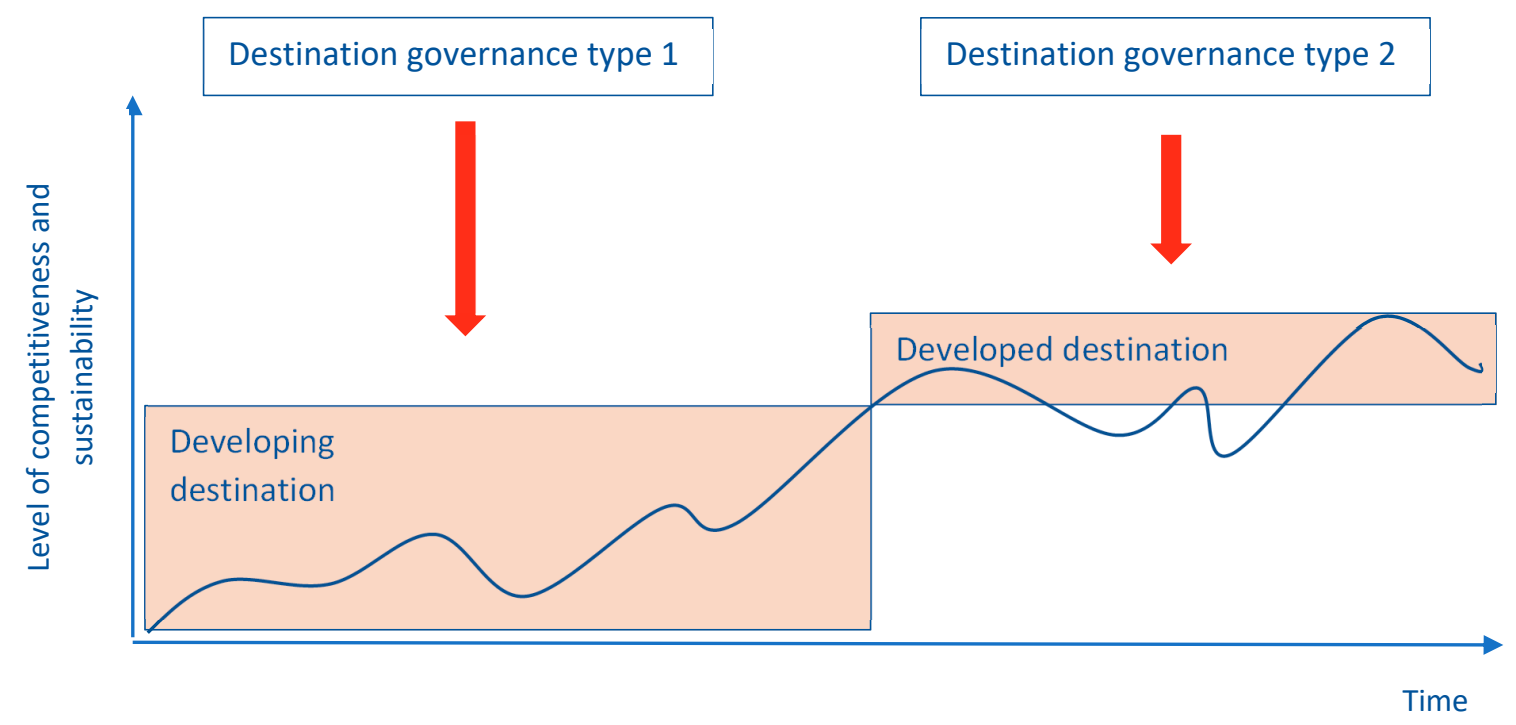

Figure 1. Destination governance typology.

The research results complement and extend quantitative measures of destination competitiveness, related to tourist numbers and GDP, which appear to still be relevant in many developing destinations. However, these quantitative measures need to go hand in hand with social and environmental indicators [112]. Therefore, the optimal way of measuring global destination competitiveness is by deploying a model that makes a distinction between developing and developed destinations, each with their set of destination governance priorities. However, global destination governance priorities (common to both destination governance types) are also being identified, and can be seen as long-term and basic priorities for both types of destinations, while in-cluster priorities have more relevance for each competitive set. Therefore, governance types are mainly understood here as stakeholder importance and the consequent power relationship architecture between different types of actors at the destination. The model does not consider governance arrangements or processes in either developed or developing destinations. Future research can investigate the precise inside cluster weighing of predictors, in order to develop a weighing scheme for both developing and developed destinations.

Identified predictors of global destination excellence should provide stakeholders in both developing and developed destinations with an early discussion basis for anticipating change and making timely destination governance arrangements and adopting a long-term global perspective, regardless of the current level of development. Going a step deeper into the in-cluster predictors, destinations can decide on a set of governance priorities of more direct relevance to competitiveness inside one's own competitive set. 


\section{Conclusions}

The article started by giving an overview of the literature on destination competitiveness, the predictors of destination competitiveness and sustainability and of destination planning, development and governance. It then presented an exhaustive overview of approaches to measuring destination competitiveness and sustainability-from the number of indicators used (observable variables), concepts used to classify the indicators (non-observable mediating variables) and methodology used to the analysis of the data collected. There are both inductive and deductive approaches in this research field, but the main weakness in inductive approaches seems to be the creation of one single model of destination competitiveness to be applied to all destinations, usually by applying PCA (principal component analysis). This statistical method is rather a dimension reduction method than a proper clustering method. In order to fill the research gap and answer the first research question, this research deployed a novel method-a two-step cluster analysis—and identified two major global types of destination competitiveness-one for more developed destinations and the other for less developed destinations. The created model gives a comprehendible list of major predictors for belonging to either one of the two competitive sets, thereby answering the second research question. The model also provides a within-cluster importance rank for both competitive sets, thereby answering the third research question. In this way, a very usable and action-oriented model was created for both academicians and destination managers to be used in further research globally. The identified predictors can provide the most important factors of moving the destination from a lower-level development to a higher-level development. In practice, this would usually mean either development or consolidation for an already developed destination that has experienced a downturn.

The major limitation of this study relates to the methodological problems when attempting to aggregate large amounts of data from different fields of society. The second limitation relates to the induced model with two major types of destination competitiveness and sustainability, as it is inevitably a logical simplification of the reality of global destinations. Although it can be useful for starting a discussion on major types of global destination competitiveness, sustainability and governance arrangements, it is still far from identifying all boundary conditions and outcomes of successful destination development. Another important issue is that some important indicators from the literature (e.g., air quality) are not included in this list, but have been demonstrated to be of great importance in many destinations. This is why contingencies regarding the application of the model in different regional, national or local contexts should be further identified and analyzed with the help of other research methods.

The major goal of the study was to contribute to the literature on destination governance, by deploying a novel method for creating a destination typology based on stakeholder prioritization by extracting major predictors of belonging to each one of the two types: developed and developing destinations. Further research should concentrate on extracting further specific governance types according to specific geographic areas, narrower competitive sets and other aspects of destination governance, beyond stakeholders-power relations, governance structures or processes.

This novel methodological analysis approach to destination competitiveness strengthens the indicator-driven policy analysis by creating a reference model with two different destination types. This is of relevance for both academics as well as practitioners. Furthermore, the results demonstrate the importance of making a distinction between developed and developing destinations when considering different competitiveness and sustainability models. The results also enable the creation of weighing schemes to more precisely measure destination competitiveness and sustainability in different contexts.

Author Contributions: Conceptualization, I.P.; Methodology, M.D. and I.P.; Software, I.P.; Validation, T.M.N. and S.P.P.; Writing-original draft preparation, I.P., T.M.N. and S.P.P.; Writing—review and editing, M.D.; Supervision, M.D.; All authors have read and agreed to the published version of the manuscript.

Funding: This research received no external funding.

Conflicts of Interest: The authors declare no conflict of interest. 


\section{References}

1. Pechlaner, H.; Zacher, D.; Eckert, C.; Petersik, L. Joint responsibility and understanding of resilience from a DMO perspective-An analysis of different situations in Bavarian tourism destinations. Int. J. Tour. Cities 2018, 5, 146-168. [CrossRef]

2. Paunović, I.; Jovanović, V. Implementation of Sustainable Tourism in the German Alps: A Case Study. Sustainability 2017, 9, 226. [CrossRef]

3. Pechlaner, H.; Volgger, M.; Zehrer, A. Tourismus und Wissenschaft oder Tourismuswissenschaft? Ein weiterer Erklrungsversuch. In Tourismus und Wissenschaft: Wirtschaftliche, Politische und Gesselschaftliche Perspektiven; Pechlaner, H., Zehrer, A., Eds.; Erich Schmidt Verlag: Berlin, Germany, 2017.

4. Saarinen, J. The Transformation of a Tourist Destination-Theory and Case Studies on the Production of Local Geographies in Tourism in Finnish Lapland. Nordia Geographical Publications 2001, 30, 105.

5. Jafari, J. The Scientification of Tourism. In Hosts and Guests Revisited: Tourism Issues of the 21st Century; Cognizant: New York, NY, USA, 2001; pp. 28-41.

6. Assaf, A.G.; Josiassen, A. Identifying and Ranking the Determinants of Tourism Performance. J. Travel Res. 2011, 51, 388-399. [CrossRef]

7. Crotti, R.; Misrahi, T. The Travel E Tourism Competitiveness Report 2017; World Economic Forum: Cologny, Switzerland, 2017.

8. Crotti, R.; Misrahi, T. The Travel E Tourism Competitiveness Report 2015; World Economic Forum: Cologny, Switzerland, 2015.

9. Dwyer, L.; Kim, C. Destination Competitiveness: Determinants and Indicators. Curr. Issues Tour. 2003, 6, 369-414. [CrossRef]

10. Crouch, G.I. Destination Competitiveness: An Analysis of Determinant Attributes. J. Travel Res. 2010, 50, 27-45. [CrossRef]

11. Alebaki, M.; Koutsouris, A. Wine Tourism Destinations Across the Life-Cycle: A Comparison of Northern Greece, Peloponnese and Crete. In Wine Tourism Destination Management and Marketing; Palgrave Macmillan: London, UK, 2019; pp. 463-482.

12. Butler, R.W.E. The Tourism Area Life Cycle, Vol. 1: Applications and Modifications; Channel View Publications: Clevedon, UK, 2006.

13. Buhalis, D. Marketing the competitive destination of the future. Tour. Manag. 2000, 21, 97-116. [CrossRef]

14. Dictionary, C. Competition: Meaning in the Cambridge English Dictionary. Available online: https://dictionary. cambridge.org/de/worterbuch/englisch/competition (accessed on 20 February 2020).

15. Porter, M.E. Competitive Advantage: Creating and Sustaining Superior Performance; The Free Press: New York, NY, USA, 1985; p. 557.

16. Teodorovic, M.; Popesku, J. Serbia's competitive position in the regional tourism destination market. Eur. J. Appl. Econ. 2017, 14, 1-12. [CrossRef]

17. Popesku, J.; Pavlović, D. Competitiveness of Serbia as a tourist destination: Analysis of selected key indicators. Marketing 2013, 44, 199-210. [CrossRef]

18. Sheng, L. Regional Competition and Sustainable Development: A Game Theory Model for Tourism Destinations. Eur. Plan. Stud. 2011, 19, 669-681. [CrossRef]

19. Knežević Cvelbar, L.; Dwyer, L.; Koman, M.; Mihalič, T. Drivers of Destination Competitiveness in Tourism. J. Travel Res. 2016, 55, 1041-1050. [CrossRef]

20. Crouch, G.I.; Ritchie, J.R.B. The Competitive Destination: A Sustainable Tourism Perspective; Cabi Publishing: Cambridge, UK, 2003.

21. Porter, M.E. On Competition; The Harvard Business Review: Boston, MA, USA, 1998.

22. Ritchie, J.R.; Crouch, G.I. Competitiveness in International Tourism: A Framework for Understanding and Analysis. In Proceedings of the 43th Congress of Association Internationale D’Experts Scientique de Tourisme, San Carlos de Bariloche, Argentina, 17-23 October 1993; AIEST: San Carlos de Bariloche, Argentina, 1993.

23. Porter, M.E. Towards a dynamic theory of strategy. Strateg. Manag. J. 1991, 12, 95-117. [CrossRef]

24. Smith, A. An Inquiry into the Nature and Causes of the Wealth of Nations, 5th ed.; Methuen and Co.: London, UK, 1776.

25. Kozak, M. Destination benchmarking. Ann. Tour. Res. 2002, 29, 497-519. [CrossRef] 
26. Fuchs, M.; Weiermair, K. Destination Benchmarking: An Indicator-System's Potential for Exploring Guest Satisfaction. J. Travel Res. 2016, 42, 212-225. [CrossRef]

27. Zlatkovic, M. Tourism Destination Benchmarking Analysis. Eur. J. Multidiscip. Stud. 2016, 1, $283-293$. [CrossRef]

28. Lusticky, M.; Kincl, T. Tourism Destination Benchmarking: Evaluation and Selection of the Benchmarking Partners. J. Compet. 2012, 4, 99-116. [CrossRef]

29. Müller, H.; Berger, P. Benchmarking for destination management organizations: The case of Swiss cities and Alpine destination management. Tour. Rev. 2012, 67, 26-39. [CrossRef]

30. Bogan, C.E.; English, M.J. Benchmarking for Best Practices: Winning through Innovative Adoption; McGraw-Hill: New York, NY, USA, 1994.

31. Medina-Munoz, D.; Medina-Munoz, R.; Chim-Miki, A. Tourism competitiveness assessment: The current status of research in Spain and China. Tour. Econ. 2013, 19, 297-318. [CrossRef]

32. Gilbert, D. Strategic marketing planning for national tourism. Tour. Rev. 1990, 1, 18-27. [CrossRef]

33. Waligo, V.M.; Clarke, J.; Hawkins, R. Implementing sustainable tourism: A multi-stakeholder involvement management framework. Tour. Manag. 2013, 36, 342-353. [CrossRef]

34. Hall, C.M. Changing paradigms and global change: From sustainable to steady-state tourism. Tour. Recreat. Res. 2010, 35, 131-143. [CrossRef]

35. Brida, J.G.; Osti, L.; Barquet, A. Segmenting Resident Perceptions towards Tourism-a Cluster Analysis with a Multinmial Logit Model of a Mountain Community. Int. J. Tour. Res. 2010, 12, 591-602.

36. Hall, C.M. Degrowing tourism: Decroissance, sustainable consumption and steady-state tourism. Anatol. Int. J. Tour. Hosp. Res. 2009, 20, 46-61. [CrossRef]

37. Shunnaq, M.; Schwab, W.A.; Reid, M.F. Community Development Using a Sustainable Tourism Strategy: A Case Study of the Jordan River Valley Touristway. Int. J. Tour. Res. 2008, 10, 1-14. [CrossRef]

38. Pechlaner, H.; Herntrei, M.; Kofink, L. Growth strategies in mature destinations: Linking spatial planning with product development. Tour. Rev. 2009, 57, 285-307.

39. Goffi, G.; Cucculelli, M. Components of destination competitiveness. The case of small tourism destinations in Italy. Int. J. Tour. Policy 2014, 5, 296-326. [CrossRef]

40. Podovac, M.; Đorđević, N.; Milićević, S. Rural tourism in the function of life quality improvement of rural population on Goč mountain. Ekon. Poljopr. 2019, 66, 205-220. [CrossRef]

41. Henderson, J.C. Tourism in Dubai: Overcoming barriers to destination development. Int. J. Tour. Res. 2006, 8, 87-99. [CrossRef]

42. Prideaux, B. Resort Destinations-Evolution, Management and Development; Elsevier: Oxford, UK, 2009.

43. Romao, J.; Nijkamp, P. Impacts of innovation, productivity and specialization on tourism competitiveness-A spatial econometric analysis on European regions. Curr. Issues Tour. 2019, 22, 1150-1169. [CrossRef]

44. Moutinho, N.; Pritchard, A.; Pride, R. Futurecast: An exploration of key emerging megatrends in the tourism arena. In Trends in European Tourism Planning and Organisation; Costa, C., Panyik, E., Buhalis, D., Eds.; Channel View Publications: Bristol, UK, 2013; pp. 313-325.

45. Mamula, T.; Peric, N.; Vujic, N. The Contribution of Innovative Leadership Style as an Answer to Global and Business Changes. Qual. Acess Success 2019, 20, 9-14.

46. Bonadonna, A.; Giachino, C.; Truant, E. Sustainability and Mountain Tourism: The Millennial's Perspective. Sustainability 2017, 9, 1219. [CrossRef]

47. Nowak, L.I.; Bruwer, J.; Newton, S. Using winery web sites to launch relationships with Millennials. Int. J. Wine Bus. Res. 2008, 20, 53-67. [CrossRef]

48. Elliot, S.; Barth, J. Wine label design and personality preferences of millennials. J. Prod. Brand Manag. 2012, 21, 183-191. [CrossRef]

49. Higgins, L.; Wolf, M.M. Millennials as luxury wine buyers in the United States? Int. J. Wine Bus. Res. 2016, 28, 190-205. [CrossRef]

50. Goffi, G.; Cucculelli, M.; Masiero, L. Fostering tourism destination competitiveness in developing countries: The role of sustainability. J. Clean. Prod. 2019, 209, 101-115. [CrossRef]

51. Armenski, T.; Dwyer, L.; Pavluković, V. Destination Competitiveness: Public and Private Sector Tourism Management in Serbia. J. Travel Res. 2017, 57, 384-398. [CrossRef] 
52. Dwyer, L.; Dragićević, V.; Armenski, T.; Mihalic, T.; Knezevic Cvelbar, L. Achieving destination competitiveness: An importance-performance analysis of Serbia. Curr. Issues Tour. 2014, 19, 1309-1336. [CrossRef]

53. Paunović, I.; Jovanović, V. Sustainable mountain tourism in word and deed: A comparative analysis in the macro regions of the Alps and the Dinarides. Acta Geogr. Slov. 2019, 59, 59-69. [CrossRef]

54. Middleton, V.T.C. Sustainable tourism: A marketing perspective. In Tourism Sustainability: Principles to Practice; CAB International: Wallingford, UK, 1997; pp. 129-142.

55. Mihalič, T. Environmental management of a tourist destination. Tour. Manag. 2000, 21, 65-78. [CrossRef]

56. Stojanović, M.; Regodić, D.; Jovanović, V. Emisija zagađujućih materija i primena GIS-A. In Proceedings of the Synthesis 2015-International Scientific Conference of IT and Business-Related Research, Belgrade, Serbia, 16 April 2015; pp. 608-614.

57. Łapko, A.; Panasiuk, A.; Strulak-Wójcikiewicz, R.; Landowski, M. The State of Air Pollution as a Factor Determining the Assessment of a City's Tourist Attractiveness-Based on the Opinions of Polish Respondents. Sustainability 2020, 12, 1466. [CrossRef]

58. Zhang, A.; Zhong, L.; Xu, Y.; Wang, H.; Dang, L. Tourists' Perception of Haze Pollution and the Potential Impacts on Travel: Reshaping the Features of Tourism Seasonality in Beijing, China. Sustainability 2015, 7, 2397-2414. [CrossRef]

59. Paunović, I. Serbian City Tourism: Benchmarking Indicators of Sustainable Tourism for Competitive and Sustainable Development. Izv. Volggtu 2016, 180, 56-64.

60. Bulatović, I.; Stranjančević, A. Tourist Satisfaction Montenegro: Destination Management Quality Indicator. Int. J. Qual. Res. 2018, 13, 33-46. [CrossRef]

61. Ribic, B.; Voca, N.; Ilakovac, B. Concept of sustainable waste management in the city of Zagreb: Towards the implementation of circular economy approach. J. Air Waste Manag. Assoc. 2017, 67, 241-259. [CrossRef] [PubMed]

62. Ilic, M.; Nikolic, M. Waste Management benchmarking: A case study of Serbia. Habitat Int. 2016, 53, 453-460. [CrossRef]

63. Dredge, D.; Jamal, T. Mobilities on the Gold Coast, Australia: Implications for destination governance and sustainable tourism. J. Sustain. Tour. 2013, 21, 557-579. [CrossRef]

64. Angella, F.D.; De Carlo, M.; Sainaghi, R. Archetypes of destination governance: A comparison of international destinations. Tour. Rev. 2010, 65, 61-73. [CrossRef]

65. Guo, Y.; Jiang, J.; Li, S. A Sustainable Tourism Policy Research Review. Sustainability 2019, 11, 3187. [CrossRef]

66. Case, P.; Evans, L.S.; Fabinyi, M.; Cohen, P.J.; Hicks, C.C.; Prideaux, M.; Mills, D.J. Rethinking environmental leadership: The social construction of leaders and leadership in discourses of ecological crisis, development, and conservation. Leadership 2015, 11, 396-423. [CrossRef]

67. Moscardo, G. Exploring social representations of tourism planning: Issues for governance. J. Sustain. Tour. 2011, 19, 423-436. [CrossRef]

68. Conceição, C.C.; Dos Anjos, F.A.; Gadotti dos Anjos, S.J. Power Relationship in the Governance of Regional Tourism Organizations in Brazil. Sustainability 2019, 11, 3062. [CrossRef]

69. Cristofaro, M.; Leoni, L.; Baiocco, S. Promoting Co-Evolutionary Adaptations for Sustainable Tourism: The "Alpine Convention" Case. Tour. Plan. Dev. 2019, 1-20. [CrossRef]

70. Siakwah, P.; Musavengane, R.; Leonard, L. Tourism Governance and Attainment of the Sustainable Development Goals in Africa. Tour. Plan. Dev. 2019, 1-29. [CrossRef]

71. Borin, E.; Paunovic, I. The Case of Louvre-Lens: Regional Regeneration Through Cultural Innovation. In SITCON 2015; Singidunum University: Belgrade, Serbia, 2015; pp. 248-251.

72. Hassan, A.; Kennell, J.; Chaperon, S. Rhetoric and reality in Bangladesh: Elite stakeholder perceptions of the implementation of tourism policy. Tour. Recreat. Res. 2020,1-16. [CrossRef]

73. Chaperon, S. Tourism industry responses to public-private partnership arrangements for destination management organisations in small island economies: A case study of Jersey, Channel Islands. Int. J. Tour. Policy 2017, 7, 23-41.

74. Borin, E.; Donato, F. Unlocking the potential of IC in Italian cultural ecosystems. J. Intellect. Cap. 2015, 16, 285-304. [CrossRef]

75. Nadalipour, Z.; Imani Khoshkhoo, M.H.; Eftekhari, A.R. An integrated model of destination sustainable competitiveness. Compet. Rev. Int. Bus. J. 2019, 29, 314-335. [CrossRef] 
76. Arrona, A.; Franco, S.; Wilson, J.R. Public innovation through governance in place-based competitiveness policymaking. Compet. Rev. Int. Bus. J. 2020, 30, 119-136. [CrossRef]

77. Restrepo, N.; Anton Clavé, S. Institutional Thickness and Regional Tourism Development: Lessons from Antioquia, Colombia. Sustainability 2019, 11, 2568. [CrossRef]

78. Farinha, F.; Oliveira, M.; Silva, E.; Lança, R.; Pinheiro, M.; Miguel, C. Selection Process of Sustainable Indicators for the Algarve Region-Observe Project. Sustainability 2019, 11, 444. [CrossRef]

79. Yanes, A.; Zielinski, S.; Diaz Cano, M.; Kim, S.-I. Community-Based Tourism in Developing Countries: A Framework for Policy Evaluation. Sustainability 2019, 11, 2506. [CrossRef]

80. Dos Anjos, F.A.; Kennell, J. Tourism, Governance and Sustainable Development. Sustainability 2019, $11,4257$. [CrossRef]

81. Teece, D.J. Business models and dynamic capabilities. Long Range Plan. 2018, 51, 40-49. [CrossRef]

82. Posen, H.A. Ridesharing in the Sharing Economy: Should Regulators Impose Über Regulations on Uber? Iowa Law Rev. 2016, 101, 405-433.

83. Labrecque, L.I.; vor dem Esche, J.; Mathwick, C.; Novak, T.P.; Hofacker, C.F. Consumer Power: Evolution in the Digital Age. J. Interact. Mark. 2013, 27, 257-269. [CrossRef]

84. Guttentag, D. Airbnb: Disruptive innovation and the rise of an informal tourism accommodation sector. Curr. Issues Tour. 2013, 18, 1192-1217. [CrossRef]

85. Byrd, E.T. Stakeholders in Sustainable Tourism Development and their Roles: Applying Stakeholder Theory to Sustainable Tourism Development. Tour. Rev. 2007, 62, 6-13. [CrossRef]

86. Mihalic, T. Sustainable-responsible tourism discourse- towards responsble tourism. J. Clean. Prod. 2016, 111, 461-470. [CrossRef]

87. Cardenas-Garcia, P.J.; Sanchez-Rivero, M.; Pulido-Fernandez, J.I. Does Tourism Growth Influence Economic Development? J. Travel Res. 2015, 54, 206-221. [CrossRef]

88. Yasarata, M.; Altinay, L.; Burns, P.; Okumus, F. Politics and Sustainable Tourism Development-Can They Co-Exist? Voices from North Cyprus. Tour. Manag. 2010, 31, 345-356. [CrossRef]

89. Akama, J.S.; Kieti, D. Tourism and Socio-economic Development in Developing Countries: A Case Study of Mombasa Resort in Kenya. J. Sustain. Tour. 2007, 15, 735-748. [CrossRef]

90. Tosun, C.; Jenkins, C.L. The Evolution of Tourism Planning in Third-World Countries: A Critique. Prog. Tour. Hosp. Res. 1998, 4, 101-114. [CrossRef]

91. Goffi, G.; Cucculelli, M. Explaining tourism competitiveness in small and medium destinations: The Italian case. Curr. Issues Tour. 2018, 22, 2109-2139. [CrossRef]

92. Dwyer, L.; Mellor, R.; Livaic, Z.; Edwards, D.; Kim, C. Attributes of Destination Competitiveness: A Factor Analysis. Tour. Anal. 2004, 9, 91-101. [CrossRef]

93. Drakulić Kovačević, N.; Kovačević, L.; Stankov, U.; Dragićević, V.; Miletić, A. Applying destination competitiveness model to strategic tourism development of small destinations: The case of South Banat district. J. Destin. Mark. Manag. 2017, 8, 114-124. [CrossRef]

94. Cucculelli, M.; Goffi, G. Does sustainability enhance tourism destination competitiveness? Evidence from Italian Destinations of Excellence. J. Clean. Prod. 2016, 111, 370-382. [CrossRef]

95. Zehrer, A.; Smeral, E.; Hallmann, K. Destination Competitiveness-A Comparison of Subjective and Objective Indicators for Winter Sports Areas. J. Travel Res. 2016, 56, 55-66. [CrossRef]

96. Hallmann, K.; Müller, S.; Feiler, S.; Breuer, C.; Roth, R. Suppliers' perception of destination competitiveness in a winter sport resort. Tour. Rev. 2012,67, 13-21. [CrossRef]

97. Crouch, G.I. Measuring tourism competitiveness: Research, theory and the WEF index. In Proceedings of the ANZMAC Annual Conference: Australia New Zealand Marketing Academy, University of Otago, Dunedin, New Zealand, 3-5 December 2007.

98. Sarstedt, M.; Mooi, E. A Concise Guide to Market Research the Process, Data, and Methods Using IBM SPSS Statistics; Springer: Berlin/Heidelberg, Germany, 2014.

99. Báez-García, A.J.; Flores-Muñoz, F.; Gutiérrez-Barroso, J. Maturity in competing tourism destinations: The case of Tenerife. Tour. Rev. 2018, 73, 359-373. [CrossRef]

100. Franch, M.; Martini, U.; Buffa, F.; Parisi, G. 4L tourism (landscape, leisure, learning and limit): Responding to new motivations and expectations of tourists to improve the competitiveness of Alpine destinations in a sustainable way. Tour. Rev. 2008, 63, 4-14. [CrossRef] 
101. Sidor, C.; Kršák, B.; Štrba, L. Identification of Distorted Official Hospitality Statistics' and Their Impact on DMOs' Funding's Sustainability: Case Notes from Slovakia. Sustainability 2019, 11, 1084. [CrossRef]

102. Farmaki, A.; Antoniou, K.; Christou, P. Visiting the "enemy": Visitation in politically unstable destinations. Tour. Rev. 2019, 74, 293-309. [CrossRef]

103. Paunovic, I. Branding Serbia as a Tourist Destination on the Global Market. Turizam 2014, 18, 59-71. [CrossRef]

104. Gould, M. Branding a post-conflict destination: Northern Ireland. In Destination Brands-Managing Place Reputation; Butterworth-Heinemann (An Imprint of Elsevier): Oxford, UK, 2011; pp. 321-333.

105. Bunja, D. Modernizing the Croatian tourism industry. Int. J. Contemp. Hosp. Manag. 2003, 15, 126-128. [CrossRef]

106. Sirse, J.; Mihalic, T. Slovenian tourism and tourism policy: A case study. Tour. Rev. 1999, 54, 34-47. [CrossRef]

107. Pirjevec, B. Creating post-war tourist destination image. Acta Tour. 1998, 10, 95-109.

108. Wilson, P. Northern Ireland at the Smithsonian: Report on Participation in the 41st Smithsonian Folklife Festival; Department for Culture, Arts and Leisure: Northern Ireland, UK, 2008.

109. Reinhold, S.; Laesser, C.; Beritelli, P. 2014 St. Gallen Consensus on destination management. J. Destin. Mark. Manag. 2014, 4, 137-142. [CrossRef]

110. Reinhold, S.; Laesser, C.; Beritelli, P. The 2016 St. Gallen Consensus on Advances in Destination Management. J. Destin. Mark. Manag. 2018, 8, 426-431. [CrossRef]

111. Tosun, C. Challenges of Sustainable Tourism Development in the Developing World: The Case of Turkey. Tour. Manag. 2001, 22, 289-303. [CrossRef]

112. Niñerola, A.; Sánchez-Rebull, M.-V.; Hernández-Lara, A.-B. Tourism Research on Sustainability: A Bibliometric Analysis. Sustainability 2019, 11, 1377. [CrossRef]

(C) 2020 by the authors. Licensee MDPI, Basel, Switzerland. This article is an open access article distributed under the terms and conditions of the Creative Commons Attribution (CC BY) license (http://creativecommons.org/licenses/by/4.0/). 